\title{
GROWTH, NUTRIENT STATUS AND YIELD OF LE-CONTE PEAR TREES AS INFLUENCED BY SOME ORGANIC AND BIOFERTILIZER RATES COMPARED WITH CHEMICAL FERTILIZER
}

\author{
(Received: 1.11.2009)
}

\author{
By \\ S. M. Mohammed, T.A. Fayed, A.F. Esmail" and N.A. Abdou* \\ Pomology Department, Faculty of Agriculture, Cairo University and ${ }^{*}$ Horticulture Research Institute, \\ Agricultural Research Center, Giza, Egypt
}

\begin{abstract}
This investigation was carried out during the 2006 and 2007 growing seasons on a 3 year old Le-Conte pear trees (Pyrus communis L. X Pyrus pyrifolia N. ) grafted on Pyrus betulaefolia rootstock and planted at $5 \times 5$ meters apart (169 trees / faddan ) in sandy soil under drip irrigation system, at El-Kassasien Horticultural Research Station, Ismailia Governorate. One source of organic fertilizers (compost) plus natural rocks (rock phosphate + feldspare), with or without biofertilizers (phosphorein and biogein) plus humic acid plus compost tea, were compared with chemical fertilization. Application of compost with biofertilizers plus humic acid plus compost tea gave a better effect on all vegetative characteristics (growth rate of trunk diameter, shoot diameter, shoot length, number of leaves per shoot and leaf area) and chemical leaf constituents (leaf pigments, macro and micro elements, total carbohydrates, $\mathrm{C} / \mathrm{N}$ ratio, protein contents) and yield compared to other organic treatments. Also vegetative growth, nutritional status and yield were significantly increased from the first till the second season indicating the accumulation effect of organic manure plus biofertilizers plus humic acid plus compost tea. Chemical fertilizer gave the highest vegetative and yield characteristics and leaf chemical contents compared to all organic rates with or without biofertilizers, humic acid and compost tea in the two seasons of study.
\end{abstract}

Key words: biofertilizer, compost, compost tea, humic acid, pear, organic fertilizer.

\section{INTRODUCTION}

Organic fertilizers improve the physical, chemical and biological properties of nearly all soil types, adjusting soil $\mathrm{pH}$, increasing nutrient solubility and production of the plants (Zhou et al., 2001). The addition of organic manure to the soil encourages proliferation of soil micro organisms, increases microbial population and activity of microbial enzymes, viz. dehydrogenase, urease and nitrogenase (Abou-Hussein et al., 2002). Some investigators studied the effect of organic manure as compared with chemical fertilizer on different fruit crops Huilian et al. (2000) on pears, Kassem \& Marzouk, (2002) and El- Shenawy \& Fayed (2005a) on grapevines, Abou- Taleb, (2004) on pecans, Fayed, (2005) on peaches, and Fayed (2005b) on apples]. They reported that, under organic systems, soil biotic life increased as a result of the plant synthesis of more vitamins and sugar. Moreover, the addition of organic fertilizer is necessary for the best growth when compared to mineral fertilizers. Application of natural rocks (rock phosphate + feldspare) caused the release of the macro and micro elements $\mathrm{P}, \mathrm{K}, \mathrm{Ca}$ and $\mathrm{Mg}$, and converted them to soluble forms in comparison with the same mixtures (compost) without natural rocks (El-Haggar et al., 2004).

Biofertilizers are of the most importance for plant production and soil, as they play an important role in increasing vegetative characteristics (Fayed, 2005b on apple). Also, Hassan and Abou-Rayya (2003) showed that all bio-fertilizers (nitrobein, phosphorein, biogein and rhizobacterien at 10, 20,30 gm per tree) were effective in improving nutritional status of Anna apple trees.

Humic acid (polymeric polyhydroxy acid) was the most significant component of organic substances in aquatic systems. Humic acid is highly beneficial to both plants and soil; its importance for increasing microbial and mycorhizal activity, it is considered as a plant growth bio-stimulant, an effective soil enhancer; it promotes nutrient uptake (chelating agent) and improves vegetative characteristics, nutritional status and leaf pigments [Eissa et al. (2007a) and Ismail et al. (2007) on Le-Conte pear trees]. 


\section{MATERIALS AND METHODS}

This investigation was carried during the 2006 and 2007 growing seasons on 3 year old Le-Conte pear trees (Pyrus communis L. X Pyrus pyrifolia N. ) on Pyrus betulaefolia rootstock, planted at 5 $\times 5$ meters apart (169 trees / faddan) in a sandy soil under drip irrigation system at El-Kassasien Horticultural Research Station, Ismailia Governorate. The experimental soil was analyzed before starting the experiment and the data are presented in Table (1). The pear trees under investigation were nearly similar in size and shape. Two rates of organic fertilizers $[15 \mathrm{~kg}$ compost plus natural rocks ( $263 \mathrm{~g}$ rock phosphate $+3 \mathrm{~kg}$ feldspar) and $30 \mathrm{~kg}$ compost plus natural rocks (526 $\mathrm{g}$ rock phosphate $+6 \mathrm{~kg}$ feldspar)] were added in the first week of December of each season, delivering 172.5-345, 138-248.4 and 186$334.8 \mathrm{~g} \mathrm{~N}, \mathrm{P}$ and $\mathrm{K} /$ tree in two rates respectively, each with or without some stimulators (Biofertilizers, compost tea and humic acid. The stimulators were added either alone or in combination. The organic fertilizer treatments were compared with chemical fertilizer.

Table (1): Physical and chemical analysis of the experimental soil

\begin{tabular}{|l|c|c|c|}
\hline $\begin{array}{c}\text { Physical } \\
\text { character }\end{array}$ & $\%$ & $\begin{array}{c}\text { Chemical } \\
\text { character }\end{array}$ & $\%$ \\
\hline Field capacity & 11.77 & $\mathrm{CaCO}_{3}$ & 12.55 \\
Available water & 1.55 & Organic matter & 0.08 \\
Wilting point & 4.20 & $\mathrm{PH}(1: 25)$ & 7.5 \\
Coarse sand & 67.08 & $\mathrm{Ec}(\mathrm{mm}$ hos/ cm) & 6.14 \\
Fine sand & 9.5 & $\mathrm{Small} \mathrm{ESP}$ & 19.3 \\
Silt & 0.7 & $\mathrm{Ca}(\mathrm{mg} / 100 \mathrm{~g})$ & 0.14 \\
Clay & 5.2 & $\mathrm{Mg}(\mathrm{mg} / 100 \mathrm{~g})$ & 0.10 \\
Textural class & $\mathrm{Sandy}$ & $\mathrm{Na}(\mathrm{mg} / 100 \mathrm{~g})$ & 0.34 \\
& & $\mathrm{~K}(\mathrm{mg} / 100 \mathrm{~g})$ & 0.16 \\
& & $\mathrm{HCO}(\mathrm{mg} / 100 \mathrm{~g})$ & 0.17 \\
& & $\mathrm{CL}(\mathrm{mg} / 100 \mathrm{~g})$ & 0.30 \\
\hline
\end{tabular}

The used compost and natural rocks are show in Tables (2) and (3) respectively. Biofertilizers (BF.) were obtained from the Ministry of Agriculture, produced by the General Organization for Agriculture Equalization Fund (GOAEF). Two types of bio fertilizers were used, namely, Phosphorein (containing phosphate dissolvers, vesicular Arbuscular mycrohizas, and silicate bacteria) and Biogein (a nitrogenous bio fertilizer containing nitrogen fixation bacteria such as Azotobacter choroccocum). The biofertilizer were added to the wetted compost as soil application $(15 \mathrm{~cm}$ soil depth) in four equal doses each at $30 \mathrm{~g} /$ tree in December, March, June and September.

Table(2):Some chemical characteristics of the used compost

\begin{tabular}{|l|c|}
\hline \multicolumn{1}{|c|}{ Parameter } & Compost \\
\hline Cubic meter weight $(\mathrm{kg})$ & 520 \\
\hline Moisture \% & 33.5 \\
\hline Organic matter \% & 45.70 \\
\hline Organic carbon \% & 25.4 \\
\hline PH (1:10) & 7.40 \\
\hline EC & 2.3 \\
\hline C/N ratio & 22.1 \\
\hline Total N \% & 1.15 \\
\hline Total P \% & 0.92 \\
\hline Total K \% & 1.24 \\
\hline Total Mg \% & 0.86 \\
\hline Total Fe (ppm) & 1990 \\
\hline Total Mn (ppm) & 430 \\
\hline Total Zn (ppm) & 130 \\
\hline Total Cu ( ppm) & 30 \\
\hline
\end{tabular}

Compost tea was added as soil application in four doses, each at 2 liters/ tree in December, March, June and September. Compost tea was prepared by hand $(10 \mathrm{~kg}$ compost +100 liter clean water) variable period up to 10 days and is more akin to a compost watery extract than a brewed and aerated compost tea.

Table (3): Some components of natural rocks fertilizer

\begin{tabular}{|l|c|c|c|c|c|c|}
\hline $\begin{array}{c}\text { Component } \\
(\%)\end{array}$ & L.O.I & $\mathbf{S i O}_{2}$ & $\mathbf{A l O 2}$ & $\mathbf{F e O}$ & $\mathbf{C a O}$ & $\mathbf{M g O}$ \\
\hline Feldspar & 0.72 & 71.94 & 13.92 & 0.09 & 0.32 & 0.08 \\
\hline Phosphate & nil & nil & nil & nil & nil & nil \\
\hline $\begin{array}{l}\text { Component } \\
(\%)\end{array}$ & $\mathrm{K}_{2} \mathrm{O}$ & $\mathrm{Na}_{2} \mathrm{O}$ & $\mathrm{TiO}_{2}$ & $\mathrm{MnO}_{2}$ & $\mathrm{P}_{2} \mathrm{O}_{2}$ & $\mathrm{Cl}$ \\
\hline $\begin{array}{l}\text { Feldspar } \\
10.6\end{array}$ & 1.94 & 0.01 & 0.01 & 0.04 & 0.03 \\
\hline Phosphate & nil & nil & nil & nil & 22.8 & nil \\
\hline
\end{tabular}

Humic acid was added as a soil application as $50 \mathrm{ml}$ Actosol (2.9\% humic acid + 10-10-10 NPK) in 1 liter of water every other week from late June till October $15^{\text {th }}$.

Chemical fertilizers were added at the recommended rate by the Ministry of Agriculture (168, 60 and $172 \mathrm{~g} \mathrm{~N}, \mathrm{P}$ and $\mathrm{K}$ per tree/ year, respectively) in the first season and $(315,80$ and 
$312 \mathrm{~g} \mathrm{~N}, \mathrm{P}$, and $\mathrm{K}$ per tree /year, respectively) in the second season through drip irrigation system. The 17 treatments were replicated three times; each replicate was represented by 3 trees. The same treatments were applied in the second season.

During the two seasons the following parameters were recorded:

\section{1. - Vegetative growth}

2.1.1. Growth rate of the trunk diameter $(\mathrm{cm} /$ year) at $20 \mathrm{~cm}$ from soil surface was calculated each year according to the following equation; increase in trunk diameter $=$ diameter at the season end (October) - diameter at the beginning of the following season (January).

2.1.2. Length and diameter of the new shoots (cm/year): 6 new shoots were randomly chosen per tree and their length and diameter were measured at the end of each season.

\subsubsection{Number of leaves per shoot was recorded at the season end.}

2.1.4. Leaf area: Six mature leaves were taken at the third node from the base of the shoot for estimating leaf area using leaf area meter (model CL - 203, USA)

\subsection{Leaf minerals composition}

Macro and micro elements were determined in the oven dried leaf sample $\left(4-6^{\text {th }}\right.$ leaf from the base) collected at the $2^{\text {nd }}$ week of July. Leaves were dried at $70{ }^{\circ}$ for $48 \mathrm{~h}$. and used for the following analysis:

2.2.1.Total nitrogen: Total leaf (N) was determined by the modified micro keldahl Method as mentioned by Pregl (1945).

2.2.2. Total phosphorus: Total leaf $P$ was determined by wet digestion of plant materials by using sulphuric and perchloric acid as recommended by Piper (1974).

2.2.3. Total potassium: Total leaf $(K)$ was determined in the digested material using Zeiss flame photometer according to the method described by Brown and Lilliand (1946).

2.2.4. Calcium and $\mathrm{Mg}$ percentage, as well as $\mathrm{Fe}$, $\mathrm{Mn}$ and $\mathrm{Zn}$ contents (ppm) were determined using an atomic absorption spectrophotometer model 305 B (Piper, 1958).

\section{3. Leaf concentration (percentage) of total carbohydrates and proline}

These were estimated according to A.O.A.C. (1985) and Bates et al. (1973), respectively, as $\mathrm{mg} / 100 \mathrm{~g}$ D.W. Moreover, $\mathrm{C} / \mathrm{N}$ ratio and total protein $\%$ were also calculated.

\section{4. Leaf pigments}

Representative fresh leaf samples of the same physiological age and position (at the $4-6^{\text {th }}$ leaf from the base) were taken and photosynthetic pigments (chlorophyll $\mathrm{a}, \mathrm{b}$ and carotenoids) were calorimetrically determined according to Mackinney (1941).

\subsection{Fruiting measurements}

2.5.1. Fruit set percentage: The total number of flowers on each limb was counted at full bloom. The number of set fruit was counted on the same limbs after one month from full bloom. Fruit set percentage was calculated as follows:

Fruit set percentage $=\frac{\text { Number of developing fruitlets }}{\text { Total number of flower }} \times 100$ 2.5.2. Yield per tree: Fruits were harvested at maturity stage (the end week of August), from each tree of various replicates and yield was recorded, as number and weight in kilograms.

\subsection{Statistical analysis}

The obtained data were tabulated and statistically analysed according to the split plot design (Sendecor and Cochran, 1980). The value means were compared using LSD method at $5 \%$ level. The percentages were transferred to the arcsine to find the binomial percentages according to (Steel and Torrie, 1980).

\section{RESULTS AND DISCUSSION}

\subsection{Growth rate of trunk diameter $(\mathrm{cm} / \mathrm{year})$}

Trunk diameter was significantly affected by the different rates of fertilization throughout the two seasons of the study. Table (4) show that growth rate of trunk diameter was significantly higher in the second season $(1.96 \mathrm{~cm})$ than in the first one $(1.71 \mathrm{~cm})$. This might be due to their long time or accumulative effect since the tested treatment was applied on the same trees for the two seasons. Also, chemical fertilizer gave the highest trunk circumference $(2.33 \mathrm{~cm})$ followed by compost $2(30 \mathrm{~kg} /$ tree $)$ treatment $(1.61 \mathrm{~cm})$, and then compost at compost 1 (15kg / tree) treatment $(1.56 \mathrm{~cm})$. Interaction study between organic rates (compost) and stimulators (BF., humic acid and compost tea) and the highest significant value was compost 2 (30 kg / tree) plus bio-fertilization plus humic acid plus compost 1 tea treatment $(1.87 \mathrm{~cm})$ compared with other organic treatment. The lowest trunk circumference was obtained from compost 1 without any addition $(1.25 \mathrm{~cm})$. These results are in harmony with those reported by $\mathrm{Li}$ et al., (1997) on pear, Fayed (2005b) on apple, Kabeel (2004) on peach cv. Meet-Ghamr; El-Shenawy and Fayed (2005) on grapevine cv. Crimson and Abd-Rabou (2006) on mango and avocado seedlings.

\subsection{Length of the current year shoots}

Table (4) shows that new shoot length was significantly increased by different treatments in the two seasons. The second season was better than the first one $(38.75 \mathrm{~cm}$ and $36.79 \mathrm{~cm})$. The highest new shoot length was obtained with 


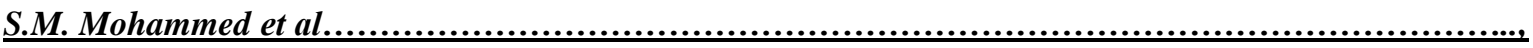

Table (4): Effect of organic and bio-fertilizer treatments on vegetative characters of "LeConte" pear tree compared to chemical fertilization $(2006 \&$ 2007).

\begin{tabular}{|c|c|c|c|c|c|c|c|c|c|c|c|}
\hline \multicolumn{3}{|c|}{ Treatments } & \multicolumn{3}{|c|}{$\begin{array}{c}\text { Growth rate of trunk } \\
\text { diameter }(\mathrm{cm} / \text { year })\end{array}$} & \multicolumn{3}{|c|}{ Shoot length $(\mathrm{cm})$} & \multicolumn{3}{|c|}{ Shoot diameter $(\mathbf{c m})$} \\
\hline & $\begin{array}{l}\text { rganic } \\
\text { rtilizers }\end{array}$ & Stimulators & 2006 & 2007 & Av & 2006 & 2007 & Av & 2006 & 2007 & Av \\
\hline \multirow{8}{*}{\multicolumn{2}{|c|}{ 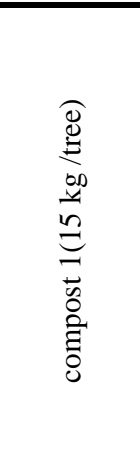 }} & without & 1.16 & 1.33 & 1.25 & 27.60 & 29.34 & 28.47 & 0.37 & 0.39 & 0.38 \\
\hline & & Bio-Fertilizer & 1.35 & 1.61 & 1.48 & 31.96 & 34.21 & 33.09 & 0.42 & 0.44 & 0.43 \\
\hline & & Compost tea & 1.29 & 1.54 & 1.42 & 31.29 & 32.78 & 32.03 & 0.41 & 0.43 & 0.42 \\
\hline & & Humic acid & 1.43 & 1.68 & 1.56 & 32.96 & 35.00 & 33.98 & 0.44 & 0.46 & 0.45 \\
\hline & & Bio + Tea & 1.50 & 1.72 & 1.61 & 35.05 & 37.07 & 36.06 & 0.53 & 0.55 & 0.54 \\
\hline & & Tea + Humic & 1.54 & 1.76 & 1.65 & 35.61 & 37.57 & 36.59 & 0.56 & 0.58 & 0.57 \\
\hline & & Bio + Humic & 1.62 & 1.82 & 1.72 & 36.19 & 38.17 & 37.18 & 0.58 & 0.60 & 0.59 \\
\hline & & Bio + Tea + Humic & 1.70 & 1.95 & 1.83 & 38.29 & 40.28 & 39.28 & 0.67 & 0.69 & 0.68 \\
\hline & & Av & 1.45 & 1.68 & 1.56 & 33.62 & 35.55 & 34.59 & 0.50 & 0.52 & 0.51 \\
\hline \multirow{8}{*}{\multicolumn{2}{|c|}{ 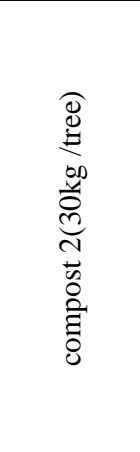 }} & without & 1.20 & 1.38 & 1.29 & 29.04 & 31.02 & 30.03 & 0.41 & 0.43 & 0.42 \\
\hline & & Bio-Fertilizer & 1.38 & 1.65 & 1.52 & 34.27 & 36.30 & 35.28 & 0.49 & 0.51 & 0.50 \\
\hline & & Compost tea & 1.33 & 1.59 & 1.46 & 33.14 & 35.42 & 34.28 & 0.47 & 0.49 & 0.48 \\
\hline & & Humic acid & 1.48 & 1.72 & 1.60 & 34.90 & 36.89 & 35.90 & 0.51 & 0.53 & 0.52 \\
\hline & & Bio + Tea & 1.54 & 1.76 & 1.65 & 36.50 & 38.37 & 37.44 & 0.59 & 0.61 & 0.60 \\
\hline & & Tea + Humic & 1.60 & 1.81 & 1.70 & 37.12 & 39.20 & 38.16 & 0.61 & 0.63 & 0.62 \\
\hline & & Bio + Humic & 1.66 & 1.88 & 1.77 & 37.69 & 39.98 & 38.69 & 0.60 & 0.65 & 0.63 \\
\hline & & Bio + Tea + Humic & 1.78 & 1.95 & 1.87 & 38.80 & 40.46 & 39.63 & 0.71 & 0.73 & 0.72 \\
\hline & & $\mathrm{Av}$ & 1.50 & 1.72 & 1.61 & 35.18 & 37.17 & 36.17 & 0.55 & 0.57 & 0.56 \\
\hline & emical f & ertilizer $(\mathrm{N}, \mathrm{P}, \mathrm{K})$ & 2.18 & 2.48 & 2.33 & 41.56 & 43.52 & 42.54 & 0.77 & 0.79 & 0.78 \\
\hline \multirow{8}{*}{ 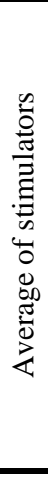 } & withou & & 1.18 & 1.35 & 1.27 & 28.32 & 30.18 & 29.25 & 0.39 & 0.41 & 0.40 \\
\hline & Bio-Fe & ertilizer & 1.36 & 1.63 & 1.50 & 33.11 & 35.25 & 34.18 & 0.45 & 0.47 & 0.46 \\
\hline & Compc & ost tea & 1.31 & 1.56 & 1.44 & 32.21 & 34.10 & 33.15 & 0.44 & 0.46 & 0.45 \\
\hline & Humic & acid & 1.45 & 1.70 & 1.58 & 33.93 & 35.94 & 34.94 & 0.47 & 0.49 & 0.48 \\
\hline & $\mathrm{Bio}+$ & Tea & 1.52 & 1.74 & 1.63 & 35.77 & 37.72 & 36.75 & 0.56 & 0.58 & 0.57 \\
\hline & Tea +1 & Humic & 1.57 & 1.78 & 1.67 & 36.36 & 38.38 & 37.37 & 0.58 & 0.60 & 0.59 \\
\hline & Bio + & Humic & 1.64 & 1.85 & 1.74 & 36.94 & 39.07 & 37.93 & 0.59 & 0.62 & 0.60 \\
\hline & $\mathrm{Bio}+$ & Tea + Humic & 1.74 & 1.95 & 1.85 & 38.54 & 40.37 & 39.45 & 0.69 & 0.71 & 0.70 \\
\hline & & General Av & 1.71 & 1.96 & & 36.79 & 38.75 & & 0.61 & 0.63 & \\
\hline \multicolumn{12}{|c|}{ L.S.D at $5 \%$ level at : } \\
\hline \multicolumn{3}{|c|}{ Seasons } & \multicolumn{3}{|c|}{0.08} & \multicolumn{3}{|c|}{0.23} & \multicolumn{3}{|c|}{0.01} \\
\hline \multicolumn{3}{|c|}{ compost } & \multicolumn{3}{|c|}{0.02} & \multicolumn{3}{|c|}{0.21} & \multicolumn{3}{|c|}{0.01} \\
\hline \multicolumn{3}{|c|}{ Stimulators } & \multicolumn{3}{|c|}{0.01} & \multicolumn{3}{|c|}{0.45} & \multicolumn{3}{|c|}{0.02} \\
\hline \multicolumn{3}{|c|}{ Seasons X Compost } & \multicolumn{3}{|c|}{0.03} & \multicolumn{3}{|c|}{0.39} & \multicolumn{3}{|c|}{0.02} \\
\hline \multicolumn{3}{|c|}{ Compost X Stimulators } & & 0.02 & & & 0.79 & & & 0.04 & \\
\hline & $\begin{array}{l}\text { Seasor } \\
\text { Stimul }\end{array}$ & $\begin{array}{l}\text { ns X Compost X } \\
\text { lators }\end{array}$ & & NS & & & 1.11 & & & 0.05 & \\
\hline
\end{tabular}


chemical fertilizer treatment $(42.54 \mathrm{~cm})$, followed by compost $2(30 \mathrm{~kg} / \mathrm{tree})$ treatment $(36.17 \mathrm{~cm})$, then organic fertilizer compost 1 (15 kg/tree) treatment $(34.59 \mathrm{~cm})$. Concerning the interaction between (compost) and stimulators (BF, humic acid and compost tea) the data revealed that the highest significant value was recorded for compost 2 (30 kg / tree) plus bio-fertilization plus humic acid plus compost tea treatment $(39.63 \mathrm{~cm})$ compared with other organic treatments, while the lowest new shoot length was obtained from compost treatment without any addition (28.47 $\mathrm{cm})$. The obtained results are in disagreement with the finding of Fayed (2005a) on peach. Similar results were obtained on apple by Fayed, (2005 b), El-Shenawy and Fayed( 2005) and Ahmed et al., (1997) on grapevine and Kabeel et al., (2005) on apricot cv. Canino and Abd-Rabou, (2006) on mango and avocado seedlings.

\section{3. Shoot diameter $(\mathrm{cm})$}

The average shoot diameter was significantly affected by different treatments in both seasons. Table (4) shows that shoot diameter was significantly greater in the $2^{\text {nd }}$ season $(0.63 \mathrm{~cm})$ than in the first one $(0.61 \mathrm{~cm})$. The shoot diameter was at the highest values with the chemical fertilizer treatment followed by the compost 2 (30 $\mathrm{kg} /$ tree) treatment and then the compost 1 (15 $\mathrm{kg} /$ tree) treatment. Interaction between organic fertilization rates (compost) and stimulators (BF, humic acid and compost tea) showed that the highest significant value was recorded for compost 2 (30 kg / tree) plus bio-fertilization plus humic acid plus compost tea treatment $(0.72 \mathrm{~cm})$ compared with the other organic treatments. Moreover, the difference between the chemical fertilizer treatment and the organic fertilizer plus bio- fertilizer treatments in the first season was so limited compared to the same treatments in the second season. This could support the previous finding that bio-fertilizer treatments gave their effect at long time. These results are confirmed by those obtained by Roan Sufeng (1998) on pear, Kabeel (2004) and Fayed (2005a) on peach, Ahmed et al. (1997), El-Shenawy and Fayed( 2005) and Fayed (2005b) on apple.

\subsection{Number of leaves / shoot}

Data in Table (5) indicate that the number of leaves / shoot was the significantly affected by different treatments in both seasons. Number of leaves / shoot was higher in the second season (19.95) than the first one (19.19). The highest number of leaves / shoot was obtained with chemical fertilizer treatment (22.75) followed by the compost $2(30 \mathrm{~kg} /$ tree $)$ treatment $(18.55)$, then the compost1 (15 kg/tree) treatment (17.41) compared with the other organic treatments. Interaction between organic fertilization rates (compost) and stimulators (BF., humic acid and compost tea) showed that the highest significant value was recorded for compost 2 (30 kg / tree) plus bio-fertilization plus humic acid plus compost tea treatment (21.38) followed by compost1 (15 $\mathrm{kg} /$ tree) plus bio-fertilization plus humic acid plus compost tea treatment (21.17) compared with other organic treatments. The lowest number of leaves / shoot was obtained from compost1 treatment without any addition (14.56). Results of the present study confirm the previous findings of Roan Sufeng (1998) and Ismail et al. (2007) on pear, Fayed (2005b) on Anna apple, El-Shenawy and Fayed (2005) on grape

\subsection{Leaf area $\left(\mathrm{cm}^{2}\right)$}

It is evident from the data in Table (5) that organic fertilizer plus bio-fertilizer, humic acid and compost tea treatments significantly increased leaf area compared with the same organic fertilizer alone in the two seasons. Also, leaf area in the second season was higher than that in the first one. In addition, the chemical fertilizer treatment resulted in the greatest average of leaf area (35.13 $\mathrm{cm}^{2}$ ) followed by compost2 (30 kg / tree) treatment $\left(30.22 \mathrm{~cm}^{2}\right)$, then compost1 (15 kg / tree) treatment $\left(28.69 \mathrm{~cm}^{2}\right)$. Interaction between organic fertilization rates (compost) and stimulators (BF, humic acid and compost tea) showed that the highest significant value was recorded for compost 2 (30 kg / tree) plus biofertilizer plus humic acid plus compost tea treatment $\left(33.90 \mathrm{~cm}^{2}\right)$ followed by compost 1 (15 $\mathrm{kg} /$ tree) plus bio-fertilization plus humic acid plus compost tea treatment $\left(32.79 \mathrm{~cm}^{2}\right)$, compared with other organic treatments. Meanwhile, trees receiving the organic fertilization (compost 1) only had the lowest leaf area value $\left(25.34 \mathrm{~cm}^{2}\right)$. The obtained results are in disharmony with those reported by El-Shenawy and Fayed (2005) on grape, Fayed (2005a) on peach, Fayed (2005b) on apple and Hegazi et al. (2007) on olive.

\subsection{Leaf mineral contents}

\subsubsection{Leaf nitrogen (\%)}

Data in Table (6) show that leaf $\mathrm{N} \%$ was significantly affected by the different treatments in both seasons. The leaf nitrogen $\%$ was generally higher in the second season $(2.37 \%)$ than in the first one $(2.34 \%)$. 
Table (5): Effect of organic and bio-fertilizer treatments on vegetative characters of "LeConte" pear tree compared with chemical fertilization $(2006 \& 2007)$.

\begin{tabular}{|c|c|c|c|c|c|c|c|}
\hline \multicolumn{2}{|r|}{ Treatments } & \multicolumn{3}{|c|}{ No. of leaves/shoot } & \multicolumn{3}{|c|}{ Leaf area $\left(\mathrm{cm}^{2}\right)$} \\
\hline $\begin{array}{c}\text { Organic } \\
\text { fertilizers }\end{array}$ & Stimulators & 2006 & 2007 & Av & 2006 & 2007 & Av \\
\hline \multirow{8}{*}{ 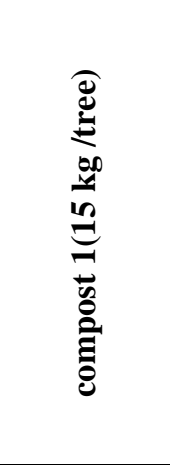 } & without & 14.51 & 14.61 & 14.56 & 25.22 & 25.45 & 25.34 \\
\hline & Bio-Fertilizer & 15.81 & 16.31 & 16.06 & 26.92 & 27.26 & 27.09 \\
\hline & Compost tea & 15.64 & 15.54 & 15.59 & 26.38 & 26.92 & 26.65 \\
\hline & Humic acid & 16.38 & 16.68 & 16.53 & 28.04 & 28.00 & 28.02 \\
\hline & $\mathrm{Bio}+\mathrm{Tea}$ & 17.53 & 18.21 & 17.87 & 29.47 & 29.37 & 29.42 \\
\hline & Tea + Humic & 18.18 & 18.86 & 18.52 & 29.65 & 30.02 & 29.84 \\
\hline & Bio + Humic & 18.42 & 19.50 & 18.96 & 30.01 & 30.80 & 30.41 \\
\hline & Bio + Tea + Humic & 20.99 & 21.35 & 21.17 & 32.15 & 33.43 & 32.79 \\
\hline & Av & 17.18 & 17.63 & 17.41 & 28.48 & 28.91 & 28.69 \\
\hline \multirow{8}{*}{ 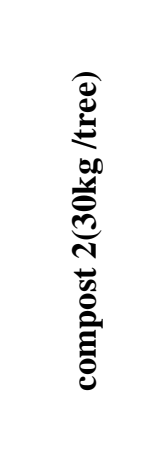 } & without & 14.90 & 15.14 & 15.02 & 26.05 & 26.29 & 26.17 \\
\hline & Bio-Fertilizer & 16.69 & 17.86 & 17.28 & 28.95 & 28.48 & 28.72 \\
\hline & Compost tea & 16.60 & 17.47 & 17.03 & 28.50 & 28.23 & 28.36 \\
\hline & Humic acid & 17.12 & 17.99 & 17.56 & 29.57 & 29.66 & 29.61 \\
\hline & $\mathrm{Bio}+\mathrm{Tea}$ & 18.81 & 19.88 & 19.34 & 30.44 & 31.60 & 31.02 \\
\hline & Tea + Humic & 19.58 & 20.66 & 20.12 & 31.07 & 32.33 & 31.70 \\
\hline & Bio + Humic & 20.28 & 20.99 & 20.64 & 31.59 & 33.01 & 32.30 \\
\hline & Bio + Tea + Humic & 21.08 & 21.68 & 21.38 & 33.24 & 34.55 & 33.90 \\
\hline & Av & 18.13 & 18.96 & 18.55 & 29.93 & 30.52 & 30.22 \\
\hline \multicolumn{2}{|c|}{ Chemical fertilizer $(\mathrm{N}, \mathrm{P}, \mathrm{K})$} & 22.24 & 23.27 & 22.75 & 34.74 & 35.53 & 35.13 \\
\hline \multirow{8}{*}{ 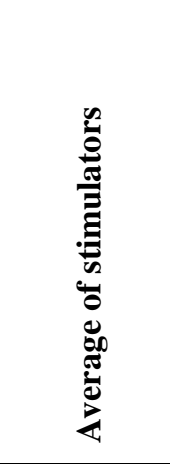 } & without & 14.70 & 14.87 & 14.78 & 25.63 & 25.87 & 25.75 \\
\hline & Bio-Fertilizer & 16.25 & 17.08 & 16.66 & 27.93 & 27.87 & 27.90 \\
\hline & Compost tea & 16.12 & 16.50 & 16.31 & 27.44 & 27.57 & 27.50 \\
\hline & Humic acid & 16.75 & 17.33 & 17.04 & 28.80 & 28.83 & 28.81 \\
\hline & $\mathrm{Bio}+\mathrm{Tea}$ & 18.17 & 19.04 & 18.60 & 29.95 & 30.48 & 30.21 \\
\hline & Tea + Humic & 18.88 & 19.76 & 19.32 & 30.36 & 31.17 & 30.76 \\
\hline & Bio + Humic & 19.35 & 20.24 & 19.79 & 30.80 & 31.90 & 31.35 \\
\hline & Bio + Tea + Humic & 21.03 & 21.51 & 21.27 & 32.69 & 33.99 & 33.34 \\
\hline \multicolumn{2}{|c|}{ General Av } & 19.19 & 19.95 & & 31.05 & 31.65 & \\
\hline \multicolumn{8}{|c|}{ L.S.D. at $5 \%$ level at : } \\
\hline \multicolumn{2}{|l|}{ Seasons } & \multicolumn{3}{|c|}{0.18} & \multicolumn{3}{|c|}{0.15} \\
\hline \multicolumn{2}{|c|}{ compost } & \multicolumn{3}{|c|}{0.17} & \multicolumn{3}{|c|}{0.14} \\
\hline \multicolumn{2}{|c|}{ Stimulators } & \multicolumn{3}{|c|}{0.36} & \multicolumn{3}{|c|}{0.31} \\
\hline \multicolumn{2}{|c|}{ Seasons X Compost } & \multicolumn{3}{|c|}{0.31} & \multicolumn{3}{|c|}{0.27} \\
\hline \multicolumn{2}{|c|}{ Season X Stimulators } & \multicolumn{3}{|c|}{0.50} & \multicolumn{3}{|c|}{0.44} \\
\hline \multicolumn{2}{|c|}{ Compost X Stimulators } & \multicolumn{3}{|c|}{0.62} & & 0.54 & \\
\hline Seasons & X Compost X Stimulators & & 0.87 & & & 0.76 & \\
\hline
\end{tabular}


Table (6): Effect of organic and bio - fertilizer treatments on leaf macro-elements (N, P and K) contents of "Le-Conte" pear tree compared with chemical fertilization (2006 \& 2007).

\begin{tabular}{|c|c|c|c|c|c|c|c|c|c|c|}
\hline \multicolumn{2}{|r|}{ Treatments } & \multicolumn{3}{|c|}{ Nitrogen (\%) } & \multicolumn{3}{|c|}{ Phosphorus (\%) } & \multicolumn{3}{|c|}{ Potassium (\%) } \\
\hline $\begin{array}{l}\text { Organic } \\
\text { fertilizers }\end{array}$ & Stimulators & 2006 & 2007 & Av & 2006 & 2007 & Av & 2006 & 2007 & $\mathrm{Av}$ \\
\hline \multirow{8}{*}{ 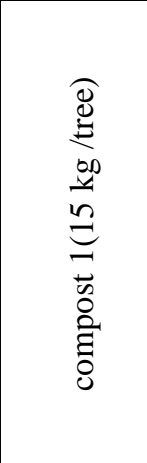 } & without & 2.16 & 2.19 & 2.17 & 0.159 & 0.161 & 0.160 & 2.14 & 2.17 & 2.15 \\
\hline & Bio-Fertilizer & 2.21 & 2.23 & 2.22 & 0.170 & 0.173 & 0.172 & 2.18 & 2.24 & 2.21 \\
\hline & Compost tea & 2.19 & 2.22 & 2.20 & 0.164 & 0.167 & 0.166 & 2.17 & 2.22 & 2.19 \\
\hline & Humic acid & 2.23 & 2.24 & 2.23 & 0.173 & 0.176 & 0.175 & 2.19 & 2.26 & 2.22 \\
\hline & Bio + Tea & 2.29 & 2.31 & 2.30 & 0.177 & 0.180 & 0.179 & 2.26 & 2.31 & 2.28 \\
\hline & Tea + Humic & 2.30 & 2.32 & 2.31 & 0.180 & 0.184 & 0.182 & 2.28 & 2.32 & 2.30 \\
\hline & Bio + Humic & 2.31 & 2.34 & 2.32 & 0.185 & 0.188 & 0.186 & 2.30 & 2.33 & 2.31 \\
\hline & Bio + Tea + Humic & 2.39 & 2.42 & 2.40 & 0.189 & 0.193 & 0.191 & 2.36 & 2.40 & 2.38 \\
\hline & $\mathrm{Av}$ & 2.26 & 2.28 & 2.27 & 0.175 & 0.178 & 0.176 & 2.26 & 2.28 & 2.27 \\
\hline \multirow{8}{*}{ 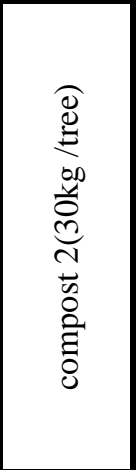 } & without & 2.18 & 2.20 & 2.19 & 0.163 & 0.166 & 0.165 & 2.16 & 2.20 & 2.18 \\
\hline & Bio-Fertilizer & 2.26 & 2.28 & 2.27 & 0.173 & 0.176 & 0.174 & 2.22 & 2.30 & 2.26 \\
\hline & Compost tea & 2.24 & 2.25 & 2.24 & 0.167 & 0.170 & 0.169 & 2.20 & 2.28 & 2.24 \\
\hline & Humic acid & 2.28 & 2.30 & 2.29 & 0.177 & 0.180 & 0.179 & 2.24 & 2.31 & 2.27 \\
\hline & $\mathrm{Bio}+\mathrm{Tea}$ & 2.33 & 2.36 & 2.34 & 0.181 & 0.184 & 0.182 & 2.32 & 2.35 & 2.33 \\
\hline & Tea + Humic & 2.35 & 2.38 & 2.36 & 0.184 & 0.187 & 0.186 & 2.34 & 2.37 & 2.35 \\
\hline & Bio + Humic & 2.37 & 2.40 & 2.38 & 0.188 & 0.191 & 0.189 & 2.35 & 2.38 & 2.36 \\
\hline & $\mathrm{Bio}+\mathrm{Tea}+$ Humic & 2.40 & 2.45 & 2.42 & 0.193 & 0.196 & 0.194 & 2.38 & 2.42 & 2.40 \\
\hline & $\mathrm{Av}$ & 2.30 & 2.32 & 2.31 & 0.178 & 0.181 & 0.180 & 2.28 & 2.32 & 2.30 \\
\hline \multicolumn{2}{|c|}{ Chemical fertilizer $(\mathrm{N}, \mathrm{P}, \mathrm{K})$} & 2.46 & 2.53 & 2.49 & 0.200 & 0.203 & 0.202 & 2.44 & 2.50 & 2.47 \\
\hline \multirow{8}{*}{ 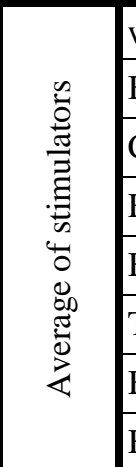 } & without & 2.17 & 2.19 & 2.18 & 0.161 & 0.163 & 0.162 & 2.15 & 2.18 & 2.16 \\
\hline & Bio-Fertilizer & 2.23 & 2.25 & 2.24 & 0.171 & 0.174 & 0.173 & 2.20 & 2.27 & 2.23 \\
\hline & Compost tea & 2.21 & 2.23 & 2.22 & 0.165 & 0.168 & 0.166 & 2.18 & 2.25 & 2.21 \\
\hline & Humic acid & 2.25 & 2.27 & 2.26 & 0.175 & 0.178 & 0.176 & 2.21 & 2.28 & 2.24 \\
\hline & Bio + Tea & 2.31 & 2.33 & 2.32 & 0.179 & 0.182 & 0.181 & 2.28 & 2.33 & 2.30 \\
\hline & Гea + Humic & 2.32 & 2.35 & 2.33 & 0.182 & 0.185 & 0.183 & 2.31 & 2.34 & 2.32 \\
\hline & Bio + Humic & 2.34 & 2.37 & 2.35 & 0.186 & 0.189 & 0.187 & 2.32 & 2.35 & 2.33 \\
\hline & Bio + Tea + Humic & 2.39 & 2. 43 & 2.41 & 0.191 & 0.194 & 0.192 & 2.37 & 2.41 & 2.39 \\
\hline \multicolumn{2}{|c|}{ General Av } & 2.34 & 2.37 & & 0.182 & 0.187 & & 2.32 & 2.36 & \\
\hline \multicolumn{11}{|c|}{ L.S.D at $5 \%$ level at : } \\
\hline \multicolumn{2}{|c|}{ Seasons } & \multicolumn{3}{|c|}{0.003} & \multicolumn{3}{|c|}{ NS } & \multicolumn{3}{|c|}{0.010} \\
\hline \multicolumn{2}{|c|}{ compost } & \multicolumn{3}{|c|}{0.003} & \multicolumn{3}{|c|}{0.002} & \multicolumn{3}{|c|}{0.010} \\
\hline \multicolumn{2}{|c|}{ Stimulators } & \multicolumn{3}{|c|}{0.006} & \multicolumn{3}{|c|}{0.004} & \multicolumn{3}{|c|}{0.021} \\
\hline \multicolumn{2}{|c|}{ Seasons X Compost } & \multicolumn{3}{|c|}{0.006} & \multicolumn{3}{|c|}{ NS } & & 0.018 & \\
\hline Season & n X Stimulators & & 0.009 & & & NS & & & 0.030 & \\
\hline Compo & ost X Stimulators & & 0.011 & & & NS & & & 0.036 & \\
\hline $\begin{array}{l}\text { Season } \\
\text { Stimuli }\end{array}$ & $\begin{array}{l}\text { ns X Compost X } \\
\text { lators }\end{array}$ & & 0.016 & & & NS & & & 0.051 & \\
\hline
\end{tabular}


Also, leaf $\mathrm{N} \%$ of the chemical fertilizer treatment in the first season was less than that in the second one. In the average, the chemical fertilizer gave the highest leaf $\mathrm{N} \%(2.49 \%)$, followed by compost 2 (30 kg per tree) treatment ( $2.31 \%)$, then compost1 (15 kg per tree) treatment $(2.27 \%)$. Interaction between organic fertilization rates (compost) and stimulators $(\mathrm{BF}$, humic acid and compost tea) showed that compost 2 (30 $\mathrm{kg} /$ tree) $+\mathrm{BF}$. + humic acid +compost tea gave the highest leaf $\mathrm{N} \%$, then compost1 $(15 \mathrm{~kg} /$ tree $)+$ $\mathrm{BF}$. + humic acid + compost tea compared with other organic treatments. Meanwhile, trees receiving the organic treatment only (compost 1) had the least leaf $\mathrm{N}$ value. These results coincide with those reported by Ystaas (1990) and Ismail (2002) on pear trees, Fayed (2005 a) on peach, and Fayed (2005 b) on apple.

\subsubsection{Leaf phosphorus (\%)}

Data in Table (6) indicate that the various fertilization treatments almost showed nonsignificant effect on leaf $\mathrm{P} \%$ in the first and second seasons. Also leaf $\mathrm{P} \%$ in the chemical fertilizer treatment was statistically equal in the two seasons. The chemical fertilizer gave the highest leaf P \% (0.202\%) followed by compost 2 (30 kg per tree) treatment $(0.180 \%)$, and then compost 1 (15 kg per tree) treatment $(0.176 \%)$. Interaction between organic fertilization rates (compost) and stimulators (BF, humic acid and compost tea) showed non-significant effect between organic fertilization treatments. These results are in line with those obtained by Hassan and Abou-Rayya (2003), Fayed (2005 a) on peach and Fayed (2005 b) on apple.

\section{6. 3. Leaf potassium (\%)}

Data in Table (6) reveal that leaf $\mathrm{K} \%$ was significantly increased in the combined treatments of biofertilizers, humic acid and compost tea in both seasons. Moreover, the leaf $\mathrm{K} \%$ was significantly higher in the second season $(2.36 \%)$ than in the first one $(2.32 \%)$. In addition, the chemical fertilizer treatment gave the highest leaf K \% (2.47\%), followed by compost 2 (30 kg per tree) treatment $(2.30 \%)$, then compost 1 (15 kg per tree) treatment (2.27). Interaction between organic rates (compost) and stimulators $(\mathrm{BF}$, humic acid and compost tea) showed that compost 2 (30 $\mathrm{kg} /$ tree) $+\mathrm{BF}$. + humic acid +compost tea gave the highest leaf potassium \% (2.40\%), then compost 1 $(15 \mathrm{~kg} / \mathrm{tree})+\mathrm{BF}$. + humic acid + compost tea (2.38\%), compared with other organic treatments. Meanwhile trees receiving the organic fertilization treatment (compost 1) only had the least leaf potassium value $(2.15 \%)$. These results are in line with those obtained by El- Haggar et al., (2004),
Fayed (2005 a) on peach, Fayed (2005 b) on, apple, and Hegazi et al. (2007) on Picual olive tree.

\section{6. 4. Leaf calcium and Magnesium (\%)}

Data concerning leaf $\mathrm{Ca}$ and $\mathrm{Mg} \%$ (Table 7) indicate that a pronounced increase in leaf $\mathrm{Ca}$ and $\mathrm{Mg} \%$ was recorded due to all organic fertilization treatments plus biofertilizer plus humic acid plus compost tea in combination or each alone in the two seasons. The second season was better than the first one. Also, the chemical fertilizer gave the highest leaf $\mathrm{Ca}$ and $\mathrm{Mg}$ content followed by compost 2 (30 kg per tree) treatment, then compost 1 (15 kg per tree) treatment. Interaction between organic fertilization rates (compost) and stimulators (BF, humic acid and compost tea) showed that compost $2(30 \mathrm{~kg} /$ tree $)+$ BF. + humic acid +compost tea gave the highest leaf $\mathrm{Ca}$ and $\mathrm{Mg}$, then compost $1(15 \mathrm{~kg} /$ tree $)+\mathrm{BF}$. + humic acid + compost tea compared with other organic treatments. Meanwhile, trees receiving the organic treatment only had the lowest leaf $\mathrm{Ca}$ and $\mathrm{Mg}$ values. These results are in contrast with those obtained by El-Morshedy (1997) on sour orange seedlings, Mahmoud and Mahmoud (1999), Fayed (2005a) on peach, and Fayed (2005b) on apple.

\section{6. 5. Leaf $\mathrm{Fe}, \mathrm{Zn}$ and $\mathrm{Mn}$ (ppm)}

Leaf concentration of $\mathrm{Fe}, \mathrm{Zn}$ and $\mathrm{Mn}$ was significantly affected by the different fertilization treatments in both seasons (Table 8). Leaf Fe, $\mathrm{Zn}$ and $\mathrm{Mn}$ of the different fertilization treatments increased significantly with increasing the application rate and high level gave the highest value of the different nutrients. Meanwhile, the chemical fertilizer treatment increased leaf concentration of $\mathrm{Fe}, \mathrm{Zn}$ and $\mathrm{Mn}$ (114.7 ppm for $\mathrm{Fe}, 54.0 \mathrm{ppm}$ for $\mathrm{Zn}$ and $55.3 \mathrm{ppm}$ for $\mathrm{Mn}$ ), compared to all organic fertilizer treatments with or without bio fertilizer plus humic acid plus compost tea. However, the interaction between organic fertilization rates (compost) and stimulators (BF, humic acid and compost tea) showed that compost $2(30 \mathrm{~kg} /$ tree $)+\mathrm{BF}$. + Humic acid +compost tea gave the highest leaf concentration of $\mathrm{Zn}, \mathrm{Fe}$ and $\mathrm{Mn}$, then compost 1 $(15 \mathrm{~kg} /$ tree $)+$ BF. + humic acid + compost tea, compared with other organic treatments. The lowest leaf contents of $\mathrm{Fe}, \mathrm{Zn}$ and $\mathrm{Mn}$ were obtained from compost 1 treatment without any addition. These results are in contrast with those obtained by El-Morshedy (1997), Mahmoud and Mahmoud (1999), Hassan and Abou-Rayya (2003), Fayed (2005b) on apple, Sharma and Bhutani (2000) Fayed (2005a) on peach, and Kassem El-Seginy (2002) on peach. 
Table (7): Effect of organic and bio-fertilizer treatments on leaf macro-elements (Ca and $\mathrm{Mg}$ ) contents of "Le-Conte" pear tree compared to chemical fertilization (2006 \& 2007)

\begin{tabular}{|c|c|c|c|c|c|c|c|}
\hline \multicolumn{2}{|r|}{ Treatments } & \multicolumn{3}{|c|}{ Calcium (\%) } & \multicolumn{3}{|c|}{ Magnesium (\%) } \\
\hline $\begin{array}{l}\text { Organic } \\
\text { fertilizers }\end{array}$ & Stimulators & 2006 & 2007 & Av & 2006 & 2007 & Av \\
\hline \multirow{8}{*}{ 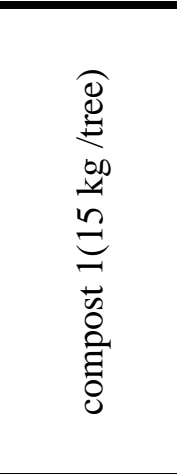 } & without & 1.37 & 1.39 & 1.38 & 0.134 & 0.137 & 0.136 \\
\hline & Bio-Fertilizer & 1.47 & 1.48 & 1.48 & 0.139 & 0.140 & 0.139 \\
\hline & Compost tea & 1.44 & 1.45 & 1.45 & 0.138 & 0.139 & 0.138 \\
\hline & Humic acid & 1.49 & 1.51 & 1.50 & 0.140 & 0.144 & 0.142 \\
\hline & Bio + Tea & 1.53 & 1.55 & 1.54 & 0.143 & 0.146 & 0.144 \\
\hline & Tea + Humic & 1.54 & 1.56 & 1.53 & 0.145 & 0.148 & 0.146 \\
\hline & Bio + Humic & 1.57 & 1.59 & 1.58 & 0.147 & 0.154 & 0.150 \\
\hline & Bio + Tea + Humic & 1.63 & 1.65 & 1.64 & 0.152 & 0.158 & 0.155 \\
\hline & $\mathrm{Av}$ & 1.51 & 1.52 & 1.51 & 0.142 & 0.146 & 0.144 \\
\hline \multirow{8}{*}{ 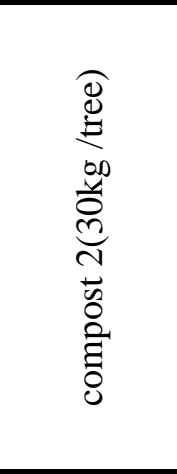 } & without & 1.39 & 1.41 & 1.39 & 0.137 & 0.138 & 0.138 \\
\hline & Bio-Fertilizer & 1.48 & 1.50 & 1.49 & 0.141 & 0.142 & 0.142 \\
\hline & Compost tea & 1.46 & 1.47 & 1.45 & 0.139 & 0.141 & 0.140 \\
\hline & Humic acid & 1.51 & 1.53 & 1.52 & 0.142 & 0.146 & 0.144 \\
\hline & $\mathrm{Bio}+\mathrm{Tea}$ & 1.53 & 1.57 & 1.55 & 0.146 & 0.148 & 0.147 \\
\hline & Tea + Humic & 1.59 & 1.59 & 1.59 & 0.147 & 0.149 & 0.148 \\
\hline & Bio + Humic & 1.61 & 1.62 & 1.61 & 0.150 & 0.157 & 0.153 \\
\hline & Bio + Tea + Humic & 1.66 & 1.69 & 1.67 & 0.154 & 0.161 & 0.157 \\
\hline & $\mathrm{Av}$ & 1.53 & 1.55 & 1.54 & 0.145 & 0.148 & 0.146 \\
\hline \multicolumn{2}{|c|}{ Chemical fertilizer (N, P, K) } & 1.727 & 1.760 & 1.743 & 0.170 & 0.173 & 0.172 \\
\hline \multirow{8}{*}{ 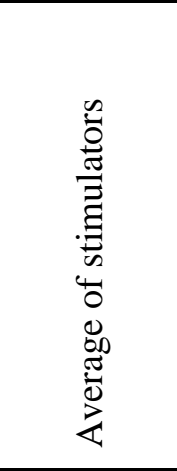 } & without & 1.38 & 1.40 & 1.39 & 0.135 & 0.137 & 0.137 \\
\hline & Bio-Fertilizer & 1.47 & 1.49 & 1.48 & 0.140 & 0.142 & 0.141 \\
\hline & Compost tea & 1.45 & 1.46 & 1.45 & 0.138 & 0.140 & 0.139 \\
\hline & Humic acid & 1.50 & 1.52 & 1.51 & 0.141 & 0.145 & 0.143 \\
\hline & Bio + Tea & 1.56 & 1.56 & 1.56 & 0.144 & 0.147 & 0.145 \\
\hline & Tea + Humic & 1.56 & 1.57 & 1.56 & 0.146 & 0.148 & 0.147 \\
\hline & Bio + Humic & 1.59 & 1.61 & 1.60 & 0.148 & 0.155 & 0.151 \\
\hline & Bio + Tea + Humic & 1.64 & 1.67 & 1.65 & 0.153 & 0.159 & 0.156 \\
\hline \multicolumn{2}{|c|}{ General Av } & 1.587 & 1.611 & & 0.152 & 0.156 & \\
\hline \multicolumn{8}{|c|}{ L.S.D at $5 \%$ level at: } \\
\hline \multicolumn{2}{|l|}{ Seasons } & \multicolumn{3}{|c|}{0.005} & \multicolumn{3}{|c|}{0.007} \\
\hline \multicolumn{2}{|c|}{ compost } & \multicolumn{3}{|c|}{0.002} & \multicolumn{3}{|c|}{0.003} \\
\hline \multicolumn{2}{|c|}{ Stimulators } & \multicolumn{3}{|c|}{0.017} & \multicolumn{3}{|c|}{0.001} \\
\hline \multicolumn{2}{|c|}{ Seasons X Compost } & \multicolumn{3}{|c|}{0.002} & \multicolumn{3}{|c|}{ NS } \\
\hline \multicolumn{2}{|c|}{ Season X Stimulators } & \multicolumn{3}{|c|}{ NS } & \multicolumn{3}{|c|}{0.001} \\
\hline \multicolumn{2}{|c|}{ Compost X Stimulators } & \multicolumn{3}{|c|}{0.029} & & 0.001 & \\
\hline $\begin{array}{l}\text { Seasons } \\
\text { Stimulat }\end{array}$ & $\begin{array}{l}\text { X Compost X } \\
\text { ors }\end{array}$ & & NS & & & 0.002 & \\
\hline
\end{tabular}


Table (8): Effect of organic and bio-fertilizer treatments on leaf micro elements contents of "Le-Conte" pear tree compared to chemical fertilization $(2006 \& 2007)$.

\begin{tabular}{|c|c|c|c|c|c|c|c|c|c|c|}
\hline \multicolumn{2}{|r|}{ Treatments } & \multicolumn{3}{|c|}{$\mathrm{Fe}(\mathrm{ppm})$} & \multicolumn{3}{|c|}{ Zn (ppm) } & \multicolumn{3}{|c|}{ Mn (ppm) } \\
\hline $\begin{array}{c}\text { Organic } \\
\text { fertilizers }\end{array}$ & Stimulators & 2006 & 2007 & Av & 2006 & 2007 & Av & 2006 & 2007 & Av \\
\hline \multirow{8}{*}{ 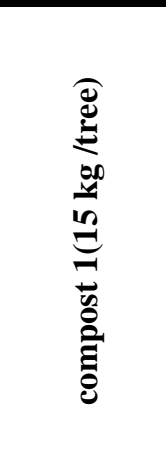 } & without & 81.7 & 84.0 & 82.8 & 39.2 & 40.3 & 39.8 & 40.6 & 42.0 & 41.3 \\
\hline & Bio-Fertilizer & 87.0 & 89.3 & 88.2 & 41.8 & 42.5 & 42.1 & 43.5 & 44.6 & 44.0 \\
\hline & Compost tea & 85.0 & 87.3 & 86.2 & 40.7 & 41.2 & 40.9 & 42.4 & 44.1 & 43.3 \\
\hline & Humic acid & 88.0 & 90.0 & 89.0 & 42.3 & 42.9 & 42.6 & 44.6 & 45.7 & 45.1 \\
\hline & Bio + Tea & 90.3 & 91.7 & 91.0 & 43.0 & 44.1 & 43.5 & 45.4 & 46.9 & 46.1 \\
\hline & Tea + Humic & 92.7 & 93.3 & 93.0 & 43.8 & 45.5 & 44.7 & 46.0 & 48.1 & 47.1 \\
\hline & Bio + Humic & 95.3 & 95.7 & 95.5 & 44.9 & 47.0 & 45.9 & 46.8 & 49.1 & 48.0 \\
\hline & $\mathrm{Bio}+\mathrm{Tea}+$ Humic & 98.0 & 99.7 & 98.8 & 46.8 & 48.4 & 47.6 & 48.6 & 51.1 & 49.8 \\
\hline & $\mathrm{Av}$ & 89.8 & 91.4 & 90.6 & 42.8 & 44.0 & 43.4 & 44.7 & 45.5 & 45.6 \\
\hline \multirow{8}{*}{ 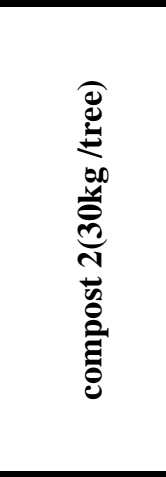 } & without & 83.3 & 86.0 & 84.7 & 40.0 & 41.0 & 40.5 & 41.3 & 42.8 & 42.0 \\
\hline & Bio-Fertilizer & 89.0 & 91.0 & 84.7 & 42.4 & 43.3 & 42.8 & 44.4 & 45.4 & 44.9 \\
\hline & Compost tea & 86.3 & 89.0 & 90.0 & 41.3 & 42.1 & 41.7 & 43.2 & 45.0 & 44.1 \\
\hline & Humic acid & 90.0 & 92.0 & 87.7 & 43.1 & 43.8 & 43.4 & 45.3 & 46.3 & 45.8 \\
\hline & Bio + Tea & 92.0 & 94.7 & 91.0 & 44.3 & 45.2 & 44.8 & 46.2 & 47.7 & 47.0 \\
\hline & Tea + Humic & 94.3 & 96.7 & 93.3 & 46.3 & 46.7 & 46.5 & 47.1 & 49.3 & 48.2 \\
\hline & Bio + Humic & 96.7 & 100.0 & 95.5 & 47.5 & 48.0 & 47.7 & 47.9 & 49.9 & 48.9 \\
\hline & $\mathrm{Bio}+\mathrm{Tea}+$ Humic & 101.0 & 105.0 & 98.3 & 48.3 & 49.4 & 48.8 & 50.3 & 52.1 & 51.2 \\
\hline & $\mathrm{Av}$ & 91.6 & 94.3 & 92.9 & 44.1 & 44.9 & 44.5 & 45.7 & 47.3 & 46.5 \\
\hline Chemical fe & ertilizer (N, P, K) & 113.0 & 116.3 & 114.7 & 53.3 & 54.7 & 54.0 & 54.5 & 56.1 & 55.3 \\
\hline \multirow{8}{*}{ 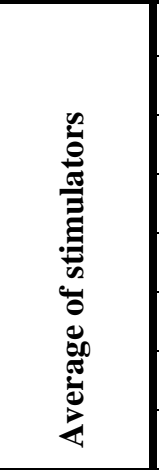 } & without & 82.5 & 85.0 & 83.8 & 39.6 & 40.7 & 40.2 & 41.0 & 42.4 & 41.7 \\
\hline & Bio-Fertilizer & 88.0 & 90.2 & 89.1 & 42.1 & 42.9 & 42.5 & 44.0 & 45.0 & 44.5 \\
\hline & Compost tea & 85.7 & 88.2 & 87.0 & 41.0 & 41.7 & 41.2 & 42.8 & 44.6 & 43.7 \\
\hline & Humic acid & 89.0 & 91.0 & 90.0 & 42.7 & 43.4 & 43.1 & 45.0 & 46.0 & 45.5 \\
\hline & Bio + Tea & 91.2 & 93.2 & 92.2 & 43.7 & 44.7 & 44.2 & 45.8 & 47.3 & 46.6 \\
\hline & Tea + Humic & 93.5 & 95.0 & 94.3 & 45.1 & 46.1 & 45.6 & 46.6 & 48.7 & 47.7 \\
\hline & Bio + Humic & 96.0 & 97.9 & 97.0 & 46.2 & 47.5 & 46.9 & 47.4 & 49.5 & 48.5 \\
\hline & Bio + Tea + Humic & 99.5 & 100.1 & 99.8 & 47.6 & 48.9 & 48.3 & 49.5 & 51.6 & 50.6 \\
\hline \multicolumn{2}{|c|}{ General Av } & 98.1 & 100.7 & & 46.7 & 47.9 & & 48.3 & 50.0 & \\
\hline \multicolumn{11}{|c|}{ L.S.D at $5 \%$ level at : } \\
\hline \multicolumn{2}{|c|}{ Seasons } & \multicolumn{3}{|c|}{0.7} & \multicolumn{3}{|c|}{0.7} & \multicolumn{3}{|c|}{0.2} \\
\hline \multicolumn{2}{|c|}{ compost } & \multicolumn{3}{|c|}{0.7} & \multicolumn{3}{|c|}{0.6} & \multicolumn{3}{|c|}{0.4} \\
\hline \multicolumn{2}{|c|}{ Stimulators } & \multicolumn{3}{|c|}{0.4} & \multicolumn{3}{|c|}{0.3} & \multicolumn{3}{|c|}{0.3} \\
\hline \multicolumn{2}{|c|}{ Seasons X Compost } & \multicolumn{3}{|c|}{ NS } & \multicolumn{3}{|c|}{ NS } & \multicolumn{3}{|c|}{ NS } \\
\hline Season & X Stimulators & & NS & & & NS & & & 0.4 & \\
\hline Compo & st X Stimulators & & 0.7 & & & 0.4 & & & 0.5 & \\
\hline $\begin{array}{l}\text { Season } \\
\text { Stimula }\end{array}$ & $\begin{array}{l}\text { s X Compost X } \\
\text { ators }\end{array}$ & & NS & & & NS & & & NS & \\
\hline
\end{tabular}


Table (9): Effect of organic and bio-fertilizer treatments on leaf protein, carbohydrate $\mathrm{C} / \mathrm{N}$ ratio and proline contents of "Le-Conte" pear tree compared to chemical fertilization ( 2006 \& 2007).

\begin{tabular}{|c|c|c|c|c|c|c|c|c|c|c|c|c|c|}
\hline \multicolumn{2}{|r|}{ Treatments } & \multicolumn{3}{|c|}{ Protein $(\%)$} & \multicolumn{3}{|c|}{ Carbohydrate (\%) } & \multicolumn{3}{|c|}{$\mathrm{C} / \mathrm{N}$ ratio } & \multicolumn{3}{|c|}{$\begin{array}{c}\text { Proline } \mathrm{mg} / 100 \mathrm{~g} \\
\text { D.W. }\end{array}$} \\
\hline హై & Stimulators & 2006 & 2007 & Av & 2006 & 2007 & Av & 2006 & 2007 & Av & 2006 & 2007 & Av \\
\hline \multirow{8}{*}{ 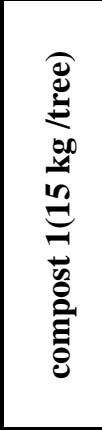 } & without & 8.52 & 8.69 & 8.60 & 9.11 & 9.96 & 9.53 & 4.20 & 4.55 & 4.37 & 0.16 & 0.14 & 0.15 \\
\hline & Bio-Fertilizer & 8.85 & 8.95 & 8.90 & 9.71 & 10.70 & 10.20 & 4.38 & 4.79 & 4.58 & 0.18 & 0.16 & 0.17 \\
\hline & Compost tea & 8.73 & 8.87 & 8.80 & 9.60 & 10.37 & 9.98 & 4.36 & 4.67 & 4.52 & 0.17 & 0.16 & 0.16 \\
\hline & Humic acid & 8.98 & 9.04 & 9.01 & 9.79 & 10.95 & 10.37 & 4.38 & 4.87 & 4.63 & 0.19 & 0.17 & 0.18 \\
\hline & Bio + Tea & 9.31 & 9.43 & 9.37 & 10.21 & 11.42 & 10.81 & 4.45 & 4.94 & 4.70 & 0.19 & 0.18 & 0.19 \\
\hline & Tea + Humic & 9.37 & 9.52 & 9.44 & 10.28 & 11.62 & 10.95 & 4.47 & 5.00 & 4.73 & 0.21 & 0.20 & 0.20 \\
\hline & Bio + Humic & 9.48 & 9.64 & 9.56 & 10.37 & 11.78 & 11.07 & 4.48 & 5.03 & 4.75 & 0.22 & 0.21 & 0.21 \\
\hline & Bio + Tea + Humic & 9.93 & 10.14 & 10.04 & 11.08 & 12.69 & 11.88 & 4.63 & 5.23 & 4.93 & 0.23 & 0.22 & 0.23 \\
\hline & Av & 9.15 & 9.29 & 9.22 & 10.01 & 11.18 & 10.59 & 4.42 & 4.89 & 4.65 & 0.19 & 0.18 & 0.18 \\
\hline \multirow{8}{*}{ 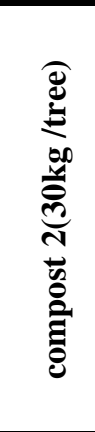 } & without & 8.75 & 8.68 & 8.68 & 9.21 & 10.20 & 9.70 & 4.22 & 4.63 & 4.43 & 0.17 & 0.15 & 0.16 \\
\hline & Bio-Fertilizer & 9.25 & 9.20 & 9.20 & 10.03 & 10.12 & 10.57 & 4.43 & 4.88 & 4.66 & 0.18 & 0.17 & 0.18 \\
\hline & Compost tea & 9.08 & 9.05 & 9.05 & 9.88 & 10.96 & 10.42 & 4.40 & 4.86 & 4.63 & 0.18 & 0.16 & 0.17 \\
\hline & Humic acid & 9.37 & 9.32 & 9.32 & 10.21 & 11.27 & 10.72 & 4.47 & 4.90 & 4.69 & 0.20 & 0.18 & 0.19 \\
\hline & Bio + Tea & 9.77 & 9.67 & 9.67 & 10.44 & 11.86 & 11.15 & 4.48 & 5.02 & 4.75 & 0.22 & 0.19 & 0.20 \\
\hline & Tea + Humic & 9.89 & 9.80 & 9.80 & 10.67 & 12.12 & 11.39 & 4.53 & 5.09 & 4.81 & 0.22 & 0.20 & 0.21 \\
\hline & Bio + Humic & 10.02 & 9.93 & 9.93 & 10.94 & 12.24 & 11.59 & 4.60 & 5.09 & 4.85 & 0.23 & 0.21 & 0.22 \\
\hline & Bio + Tea + Humic & 10.33 & 10.19 & 10.19 & 11.36 & 12.85 & 12.10 & 4.72 & 5.24 & 4.98 & 0.24 & 0.23 & 0.24 \\
\hline & $\mathrm{Av}$ & 9.40 & 9.56 & 9.48 & 10.34 & 11.57 & 10.95 & 4.48 & 4.96 & 4.72 & 0.21 & 0.19 & 0.20 \\
\hline \multicolumn{2}{|c|}{ Chemical fertilizer $(\mathrm{N}, \mathrm{P}, \mathrm{K})$} & 10.41 & 10.81 & 10.61 & 12.40 & 13.35 & 12.87 & 5.00 & 5.28 & 5.14 & 0.27 & 0.26 & 0.27 \\
\hline \multirow{8}{*}{ 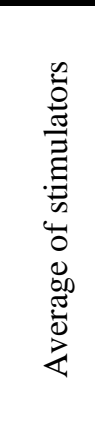 } & without & 8.63 & 8.68 & 8.65 & 9.16 & 10.08 & 9.62 & 4.21 & 4.59 & 4.40 & 0.16 & 0.14 & 0.15 \\
\hline & Bio-Fertilizer & 9.05 & 9.07 & 9.06 & 9.87 & 10.41 & 10.14 & 4.40 & 4.83 & 4.61 & 0.18 & 0.16 & 0.17 \\
\hline & Compost tea & 8.91 & 8.96 & 8.93 & 9.74 & 10.66 & 10.20 & 4.38 & 4.76 & 4.57 & 0.17 & 0.16 & 0.16 \\
\hline & Humic acid & 9.18 & 9.18 & 9.18 & 10.00 & 11.11 & 10.55 & 4.42 & 4.88 & 4.65 & 0.19 & 0.17 & 0.18 \\
\hline & Bio + Tea & 9.54 & 9.55 & 9.54 & 10.32 & 11.64 & 10.98 & 4.46 & 4.98 & 4.72 & 0.20 & 0.18 & 0.19 \\
\hline & Tea + Humic & 9.63 & 9.66 & 9.64 & 10.52 & 11.87 & 11.19 & 4.50 & 5.04 & 4.77 & 0.21 & 0.20 & 0.20 \\
\hline & Bio + Humic & 9.75 & 9.78 & 9.76 & 10.65 & 12.01 & 11.33 & 4.54 & 5.06 & 4.80 & 0.22 & 0.21 & 0.21 \\
\hline & Bio + Tea + Humic & 10.13 & 10.16 & 10.14 & 11.22 & 12.77 & 11.99 & 4.67 & 5.23 & 4.95 & 0.23 & 0.22 & 0.22 \\
\hline \multicolumn{2}{|c|}{ General Av } & 9.65 & 9.88 & & 10.91 & 12.03 & & 4.64 & 5.04 & & 0.23 & 0.21 & \\
\hline \multicolumn{14}{|c|}{ L.S.D at $5 \%$ level at : } \\
\hline \multicolumn{2}{|c|}{ Seasons } & \multicolumn{3}{|c|}{0.006} & \multicolumn{3}{|c|}{0.18} & \multicolumn{3}{|c|}{ NS } & \multicolumn{3}{|c|}{ NS } \\
\hline \multicolumn{2}{|c|}{ compost } & \multicolumn{3}{|c|}{0.037} & \multicolumn{3}{|c|}{0.13} & \multicolumn{3}{|c|}{0.058} & \multicolumn{3}{|c|}{0.03} \\
\hline Stimu & lators & \multicolumn{3}{|c|}{0.006} & & 0.28 & & & 0.018 & & & NS & \\
\hline Seasol & ns X Compost & & NS & & & 0.24 & & & NS & & & NS & \\
\hline Seasol & n X Stimulators & & 0.003 & & & 0.39 & & & NS & & & NS & \\
\hline Comp & ost X Stimulators & & 0.004 & & & 0.48 & & & 0.032 & & & NS & \\
\hline $\begin{array}{r}\text { Seasol } \\
\text { Sti }\end{array}$ & $\begin{array}{l}\text { ns X Compost X } \\
\text { mulators }\end{array}$ & & 0.005 & & & 0.68 & & & NS & & & NS & \\
\hline
\end{tabular}


Table (10): Effect of organic and bio-fertilizer treatments on leaf pigments contents of "Le-Conte" pear tree compared to chemical fertilization $(2006 \& 2007)$.

\begin{tabular}{|c|c|c|c|c|c|c|c|c|c|c|c|}
\hline \multicolumn{2}{|r|}{ Treatments } & \multicolumn{3}{|c|}{$\begin{array}{c}\text { Chlorophyll (a) } \mathrm{mg} / \mathrm{g} \\
\text { fresh weight }\end{array}$} & \multicolumn{3}{|c|}{$\begin{array}{c}\text { Chlorophyll (b) mg/g fresh } \\
\text { weight }\end{array}$} & \multicolumn{4}{|c|}{ Carotene } \\
\hline $\begin{array}{c}\text { Organic } \\
\text { fertilizers }\end{array}$ & Stimulators & 2006 & 2007 & Av & 2006 & 2007 & Av & & & 2007 & Av \\
\hline \multirow{8}{*}{ 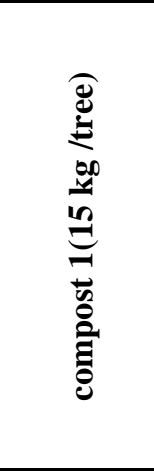 } & without & 0.61 & 0.56 & 0.59 & 0.50 & 0.51 & 0.51 & & & 0.54 & 0.53 \\
\hline & Bio-Fertilizer & 0.64 & 0.64 & 0.64 & 0.53 & 0.55 & 0.54 & & & 0.61 & 0.58 \\
\hline & Compost tea & 0.63 & 0.61 & 0.62 & 0.52 & 0.54 & 0.53 & & & 0.58 & 0.56 \\
\hline & Humic acid & 0.65 & 0.65 & 0.65 & 0.54 & 0.56 & 0.55 & & & 0.63 & 0.60 \\
\hline & Bio + Tea & 0.68 & 0.72 & 0.70 & 0.61 & 0.63 & 0.62 & & & 0.72 & 0.68 \\
\hline & Tea + Humic & 0.69 & 0.74 & 0.71 & 0.62 & 0.65 & 0.63 & & & 0.73 & 0.69 \\
\hline & Bio + Humic & 0.70 & 0.76 & 0.73 & 0.64 & 0.67 & 0.65 & & & 0.74 & 0.70 \\
\hline & Bio + Tea + Humic & 0.74 & 0.82 & 0.78 & 0.70 & 0.75 & 0.72 & & & 0.79 & 0.75 \\
\hline & $\mathrm{Av}$ & 0.67 & 0.69 & 0.68 & 0.58 & 0.60 & 0.59 & & & 0.66 & 0.63 \\
\hline \multirow{8}{*}{ 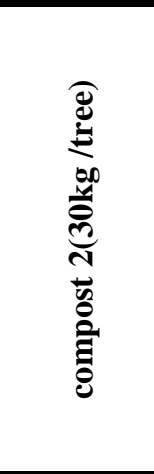 } & without & 0.62 & 0.59 & 0.60 & 0.51 & 0.52 & 0.51 & & & 0.55 & 0.54 \\
\hline & Bio-Fertilizer & 0.66 & 0.68 & 0.67 & 0.57 & 0.59 & 0.58 & & & 0.66 & 0.63 \\
\hline & Compost tea & 0.65 & 0.66 & 0.65 & 0.55 & 0.57 & 0.56 & & & 0.64 & 0.61 \\
\hline & Humic acid & 0.67 & 0.70 & 0.68 & 0.59 & 0.62 & 0.60 & & & 0.70 & 0.66 \\
\hline & Bio + Tea & 0.71 & 0.78 & 0.74 & 0.65 & 0.70 & 0.67 & & & 0.75 & 0.71 \\
\hline & Tea + Humic & 0.72 & 0.80 & 0.76 & 0.67 & 0.71 & 0.69 & & & 0.76 & 0.72 \\
\hline & Bio + Humic & 0.73 & 0.81 & 0.77 & 0.69 & 0.73 & 0.71 & & & 0.78 & 0.75 \\
\hline & Bio + Tea + Humic & 0.75 & 0.83 & 0.79 & 0.70 & 0.77 & 0.73 & & & 0.80 & 0.76 \\
\hline & $\mathrm{Av}$ & 0.69 & 0.73 & 0.71 & 0.61 & 0.65 & 0.63 & & & 0.70 & 0.67 \\
\hline \multicolumn{2}{|c|}{ Chemical fertilizer $(\mathrm{N}, \mathrm{P}, \mathrm{K})$} & 0.78 & 0.88 & 0.83 & 0.73 & 0.82 & 0.77 & & & 0.85 & 0.80 \\
\hline \multicolumn{2}{|l|}{ without } & 0.61 & 0.58 & 0.60 & 0.51 & 0.52 & 0.51 & & & 0.54 & 0.53 \\
\hline \multicolumn{2}{|c|}{ Bio-Fertilizer } & 0.65 & 0.66 & 0.65 & 0.55 & 0.57 & 0.56 & & & 0.63 & 0.60 \\
\hline Compos & tea & 0.64 & 0.64 & 0.64 & 0.54 & 0.56 & 0.55 & & & 0.61 & 0.58 \\
\hline Humic a & & 0.66 & 0.68 & 0.67 & 0.57 & 0.59 & 0.58 & & & 0.66 & 0.63 \\
\hline Bio $+\mathrm{T}$ & & 0.69 & 0.76 & 0.73 & 0.63 & 0.67 & 0.65 & & & 0.73 & 0.69 \\
\hline Tea $+\mathrm{H}$ & imic & 0.71 & 0.77 & 0.74 & 0.65 & 0.68 & 0.67 & & & 0.74 & 0.70 \\
\hline Bio + H & Imic & 0.72 & 0.79 & 0.76 & 0.67 & 0.70 & 0.69 & & & 0.76 & 0.73 \\
\hline Bio + Te & $a+$ Humic & 0.74 & 0.82 & 0.78 & 0.70 & 0.76 & 0.73 & & & 0.79 & 0.75 \\
\hline Genera & Av & 0.71 & 0.76 & & 0.64 & 0.69 & & 0.66 & 0.73 & & \\
\hline \multicolumn{12}{|c|}{ L.S.D at $5 \%$ level at : } \\
\hline \multicolumn{2}{|l|}{ Seasons } & \multicolumn{3}{|c|}{0.003} & \multicolumn{3}{|c|}{0.003} & \multicolumn{4}{|c|}{0.003} \\
\hline \multicolumn{2}{|l|}{ compost } & \multicolumn{3}{|c|}{0.003} & \multicolumn{3}{|c|}{0.003} & \multicolumn{4}{|c|}{0.003} \\
\hline \multicolumn{2}{|c|}{ Stimulators } & \multicolumn{3}{|c|}{0.007} & \multicolumn{3}{|c|}{0.007} & \multicolumn{4}{|c|}{0.066} \\
\hline Seasons X & Compost & \multicolumn{3}{|c|}{0.006} & & 0.006 & & & & & \\
\hline Season $X$ & timulators & & 0.009 & & & 0.009 & & & & & \\
\hline Compost $X$ & Stimulators & & 0.011 & & & 0.011 & & & & & \\
\hline $\begin{array}{l}\text { Seasons } \\
\text { Stimul }\end{array}$ & $\begin{array}{c}\mathrm{X} \\
\text { tors }\end{array}$ & & 0.016 & & & 0.016 & & & & & \\
\hline
\end{tabular}


Table (11): Effect of organic and bio-fertilizer treatments on fruit set and yield of "LeConte" pear tree compared to chemical fertilization (2006 \& 2007).

\begin{tabular}{|c|c|c|c|c|c|c|c|}
\hline \multicolumn{2}{|c|}{ Treatments } & \multicolumn{3}{|c|}{ Fruit set (\%) } & \multicolumn{3}{|c|}{ Yield/tree (kg) } \\
\hline $\begin{array}{c}\text { Organic } \\
\text { fertilizers }\end{array}$ & Stimulators & 2006 & 2007 & Av & 2006 & 2007 & Av \\
\hline \multirow{8}{*}{ 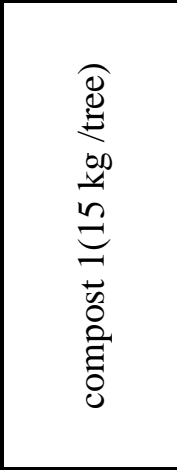 } & without & 8.28 & 9.67 & 8.97 & 15.57 & 17.35 & 16.46 \\
\hline & Bio-Fertilizer & 9.59 & 10.74 & 10.17 & 18.50 & 20.15 & 19.33 \\
\hline & Compost tea & 9.40 & 9.97 & 9.69 & 17.78 & 18.95 & 18.36 \\
\hline & Humic acid & 10.05 & 10.94 & 10.50 & 19.37 & 20.75 & 20.06 \\
\hline & $\mathrm{Bio}+\mathrm{Tea}$ & 11.09 & 11.69 & 11.39 & 23.67 & 25.01 & 24.34 \\
\hline & Tea + Humic & 11.46 & 12.59 & 12.02 & 24.71 & 25.79 & 25.25 \\
\hline & Bio + Humic & 12.03 & 13.07 & 12.55 & 25.42 & 26.82 & 26.12 \\
\hline & Bio + Tea + Humic & 14.12 & 14.57 & 14.35 & 29.12 & 30.48 & 29.80 \\
\hline & $\mathrm{Av}$ & 10.75 & 11.66 & 11.20 & 21.77 & 23.16 & 22.47 \\
\hline \multirow{8}{*}{ 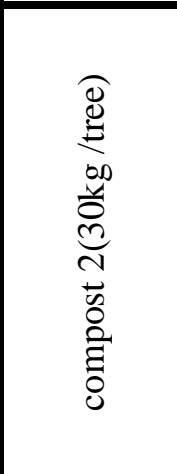 } & without & 9.10 & 9.29 & 9.19 & 16.86 & 19.42 & 18.14 \\
\hline & Bio-Fertilizer & 10.40 & 11.39 & 10.90 & 20.85 & 22.97 & 21.91 \\
\hline & Compost tea & 9.95 & 10.33 & 10.15 & 19.52 & 22.10 & 20.81 \\
\hline & Humic acid & 10.75 & 11.38 & 11.06 & 22.73 & 24.42 & 23.57 \\
\hline & Bio + Tea & 12.60 & 13.44 & 13.02 & 26.20 & 27.88 & 27.04 \\
\hline & Tea + Humic & 13.42 & 13.74 & 13.58 & 27.30 & 28.72 & 28.01 \\
\hline & Bio + Humic & 13.76 & 14.35 & 14.05 & 28.14 & 29.95 & 29.05 \\
\hline & Bio + Tea + Humic & 14.96 & 15.18 & 15.07 & 30.73 & 32.81 & 31.77 \\
\hline & Av & 11.87 & 12.39 & 12.13 & 24.04 & 26.03 & 25.04 \\
\hline \multicolumn{2}{|c|}{ Chemical fertilizer $(\mathrm{N}, \mathrm{P}, \mathrm{K})$} & 15.97 & 16.53 & 16.25 & 34.85 & 37.88 & 36.37 \\
\hline \multirow{8}{*}{ 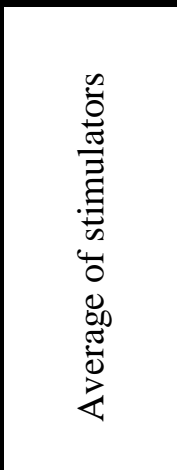 } & without & 8.69 & 9.48 & 9.08 & 16.21 & 18.38 & 17.29 \\
\hline & Bio-Fertilizer & 9.99 & 11.06 & 10.52 & 19.67 & 21.56 & 20.61 \\
\hline & Compost tea & 9.67 & 10.15 & 9.91 & 18.65 & 20.52 & 19.58 \\
\hline & Humic acid & 10.40 & 11.16 & 10.78 & 21.05 & 22.58 & 21.81 \\
\hline & $\mathrm{Bio}+\mathrm{Tea}$ & 11.84 & 12.56 & 12.20 & 24.93 & 26.44 & 25.68 \\
\hline & Tea + Humic & 12.44 & 13.16 & 12.80 & 26.00 & 27.25 & 26.62 \\
\hline & Bio + Humic & 12.89 & 13.71 & 13.30 & 26.78 & 28.38 & 27.58 \\
\hline & Bio + Tea + Humic & 14.54 & 14.87 & 14.70 & 29.92 & 31.64 & 30.78 \\
\hline \multicolumn{2}{|c|}{ General Av } & 12.86 & 13.52 & & 26.89 & 29.02 & \\
\hline \multicolumn{8}{|c|}{ L.S.D at $5 \%$ level at : } \\
\hline \multicolumn{2}{|l|}{ Seasons } & \multicolumn{3}{|c|}{0.13} & \multicolumn{3}{|c|}{0.13} \\
\hline \multicolumn{2}{|l|}{ compost } & \multicolumn{3}{|c|}{0.12} & \multicolumn{3}{|c|}{0.12} \\
\hline \multicolumn{2}{|c|}{ Stimulators } & \multicolumn{3}{|c|}{0.24} & \multicolumn{3}{|c|}{0.26} \\
\hline \multicolumn{2}{|c|}{ Seasons X Compost } & \multicolumn{3}{|c|}{0.22} & \multicolumn{3}{|c|}{0.22} \\
\hline \multicolumn{2}{|c|}{ Season X Stimulators } & \multicolumn{3}{|c|}{0.36} & \multicolumn{3}{|c|}{0.36} \\
\hline \multicolumn{2}{|c|}{ Compost X Stimulators } & \multicolumn{3}{|c|}{0.45} & & 0.45 & \\
\hline $\begin{array}{l}\text { Seasons X } \\
\text { Stimulator }\end{array}$ & Compost X & & 0.63 & & & 0.63 & \\
\hline
\end{tabular}


3.7. Leaf total carbohydrates, proteins, proline and $\mathrm{C} / \mathrm{N}$ ratio

Data presented in Table (9) reveal that total carbohydrates, $\mathrm{C} / \mathrm{N}$ ratio and total proteins were significantly increased by the addition of biofertilizer, humic acid and compost tea to organic manures. Proline showed an opposite trend. Moreover, due to the organic fertilization, leaf chemical contents (except proline) were higher in the second season than in the first one, while proline had an opposite trend. In addition, chemical fertilization resulted in the highest leaf content of all determined components, followed by compost 2 (30 kg per tree) treatment, then compost 1 (15 kg per tree) treatment. Interaction between organic rates (compost) and stimulators (BF, humic acid and compost tea) indicated that compost $2(30 \mathrm{~kg} /$ tree $)+\mathrm{BF}$. + humic acid +compost tea gave the highest leaf chemical contents compared to other organic treatment. The lowest leaf chemical contents were obtained from compost 1 without any addition. Concerning leaf proline concentration the chemical fertilizer gave the highest level compared to organic fertilization treatments. These results go in parallel with those of Ahmed et al. (1997), Mahmoud and Mahmoud (1999), Huilian et al. (2000) and Fayed (2005b) on apple, Eissa et al., (2007a) on pear, and Eissa et al., (2007b) on peach.

\subsection{Leaf pigments}

It is quite evident as shown from the data in Table (10) that leaf pigments (chlorophyll a, b and carotenoids) were significantly affected by the different treatments in both seasons. The leaf pigments concentrations were generally higher in the second season than in the first one. The chemical fertilizer gave the highest leaf pigment, followed by compost 2 (30 kg per tree) treatment, and then compost 1 (15 kg per tree) treatment. Interaction between the two main factor fertilization (organic and chemical) and bio fertilizer stimulants concerning leaf pigment concentrations were statistically significant. The highest leaf pigment concentrations were obtained with the chemical fertilizer, followed by compost 2 (30 kg per tree) +biofertilizer +humic acid + compost tea treatment, and then compost $1(15$ $\mathrm{kg}$ per tree) + biofertilizer +humic acid. Meanwhile, trees receiving the organic treatment (compost 1) only had the lowest leaf pigments value. These results are in line with those obtained by Ismail (2002) and Kabeel et al., (2005), Fayed (2005a), Fayed (2005b), Hegazi et al., (2007) and Eissa et al. (2007a) on pear, apple, peach and Picual olive, respectively.

\subsection{Fruit set and yield}

Data depicted in Table (11) indicate that fruit set percentage on spurs and yield ( $\mathrm{kg} / \mathrm{tree})$ were significantly improved by adding organic fertilizer and stimulators in the two seasons of study. Moreover the fruit set and yield were significantly higher in the second season than the first one. In addition, the chemical fertilizer treatment gave the highest value, followed by compost 2 (30 kg/tree) then compost 1 (15 $\mathrm{kg} / \mathrm{tree})$ treatment. Interaction between organic rates and stimulators showed that compost $2(30 \mathrm{~kg} /$ tree $)+$ biofertilizer+humic acid +compost tea gave the highest fruit set and yield, then compost 1 (15 kg/tree) +biofertilizer+humic acid+compost tea, compared with other organic treatment. These results are in harmony with those reported by EL-Hagger et al. (2004), Fayed (2005a) on peach, and Fayed (2005 b) on apple They recorded the stimulating effect of organic sources and rates of biofertilizers on growth rate of trunk diameter, leaf mineral contents, total carbohydrate, leaf pigments and yield. Chemical fertilizer increased proline content; this may be due to the increased chemical salinity of the soil.

\section{Conclusion and recommendation}

Application of compost with biofertilizer plus humic acid and compost tea on Le-Conte pear trees gave better effect on vegetative characteristics, chemical leaf constituents (leaf pigments, macro and micro elements, total carbohydrates, $\mathrm{C} / \mathrm{N}$ ratio , and protein contents)and yield.

\section{REFERENCES}

A.A.C.C. (2000). Grude protein- Micro kejdahl method. In approved Methods of the American Association of Cereal Chemists. Vol. II, $10^{\text {th }} \quad$ Ed. AACC method 13-46.

Abd-Rabou F.A. (2006). Effect of Microbien, Phosphorene and effective micro-organisms (EM) as bio-stimulants on growth of Avocado, and Mango seedlings. Egyptian Journal of Applied Science, 21 (6B): 673693.

Abou-Hussein S.D. El-Oksha I., El-Shorbagy T. and Gomaa A.M. (2002). Effect of cattle manure, bio fertilizers and reducing mineral fertilizer on nutrient content and yield of potato plant. Egypt. J. Hor., 29(1): 99-115.

Abou-Taleb S. A. (2004). Effect of cattle manure and reducing mineral fertilizer on growth, fruit quality and nutrient content of pecan trees. Annals of Agric. Sci. Moshohor, 42(3):1197-1214.

Ahmed F. F., Akl A.M., El-Morsy F.M. and Ragab M.A. (1997). The beneficial effects of biofertilizers on Red Roomy grapevines (Vitis vinfera L.). a- The effect on growth and nutritional status. Annals of Agriculture 
Science Moshtohor, 35 (1): 489-495.

A.O.A.C. (1985). Official Methods of Analysis, A.O.A.C. $14^{\text {th }}$ Ed.,Benjamin Franklin Station Washington DC, USA. p 494-510

Bates L.S., Waldern R.P. and Teare I.D. (1973). Rapid determination of free proline for water stress studies. Plant and Soil, 93:205207.

Brown J.D. and Lilliand O. (1946): Rapid determination of potassium and sodium in plant material and soil extract by flame photometry Proc. Amer. Soc. Hort., Sci. 48: 341-346.

Eissa Fawzia M., Faith M.A .and El-Shall S. A. (2007a). The Role of humic acid and rootstock in enhancing salt tolerance of "LeConte" pear seedlings. J. Agric. Sci. Mansoura Univ., 32 (5): 3651-3666.

Eissa, F. M., Fathi M.A. and El-Shall S.A. (2007b). Response of peach and apricot seedlings to humic acid treatments under salinity condition. J. Agric. Sci. Mansoura Univ., 32(5): 3605-3620

El-Haggar S. M., Ali B. E. Ahmed S. M. and, Hamdy M. M. M. M. (2004). Solubility of some natural rocks during composting. Proceedings of the $2^{\text {nd }}$ International Conference of Organic Agriculture. Cairo, Egypt, p. 105-116.

El-Morshedy F. A. (1997): Organic manure and sulphur interaction influence vegetative growth and elemental concentration of sour orange seedlings J. Agric. Sci. Mansoura Univ., 22 (12): 4599-4616.

El-Shenawy I. E. and Fayed T. A. (2005). Evaluation of the conventional to organic and bio-fertilizers on "Crimson seedless" grapevines in comparison with chemical fertilizers. A- Vegetative growth and nutritional status. Egypt. J. Appl. Sci., 20 (1): 192-211.

Fayed T. A. (2005a). Response of Desert Red Peach trees to organic and some biofertilizers in comparison with chemical fertilizers. A- Growth and nutritional status. Egypt. J. Appl. Sci., 20 (1): 127-143

Fayed T. A. (2005b). Effect of some organic manures and bio-fertilizers on Anna apple trees. A-Vegetative growth and leaf chemical constituents. Egypt. J. Appl. Sci., 20 (1): 159-175

Hassan H.S.A. and Abou-Rayya M.S. (2003). Effect of some bio fertilizers on leaf mineral content, yield and fruit quality of Anna apple trees grown under Northern Sinai condition. Egypt. J. Appl. Sci., 18(8B):559-574.
Hegazi E. S., El-Sonbaty M. R. Eissa M. A. Ahmed D. M. and Sharony T. F. (2007). Effect of organic and bio-fertilization on vegetative growth and flowering of Picual olive trees. World Journal of Agriculture Sciences, 3 (2) : 210-217.

Huilian X.U., Xiaojiu W. and Fujita M. (2000). Effect of organic farming practices on photosynthesis, transpiration and water relations and their contributions to fruit yield and the incidence of leaf scorch in pear trees. J. Crop Production, 3(1): 127138.

Ismail A.F. (2002). Physiological Studies on Pear Trees. M.Sc. Thesis, Fac. of Agric., Zagazig Univ., Egypt.

Ismail A.F., Hussien S.M., El- Shall S.A. and Fathi M.A. (2007). Effect of irrigation and humic acid on Le-Conte pear. J. Agric. Sci., Mansoura Univ., 32(9): 7589-7603.

Kabeel H. (2004). Influence of different rates of nitrogen and potassium on vegetative growth, fruiting aspects, fruits characteristics and leaf mineral composition of "Meet-Ghamr" peach trees. Minufiya J. Agric. Res., 29 (1): 215-234.

Kabeel H., Abdel Latif G. S. and Khalil A. A. (2005). Effect of soil application of different mineral and bio-fertilizer treatments on growth, fruiting parameters, fruit properties and leaf nutrient content of "Canino" Apricot trees. J. Agric .Sci. Mansoura Univ., 30 (3): 1583-1594.

Kassem H. A. and El Seginy A. M. (2002). Response of Florida Prince peach trees to soil and foliar application of potassium. Journal of Advanced Agriculture Research, 7 (1): 103-115.

Kassem H. A. and Marzouk H. A. (2002). Effect of organic and / or mineral nitrogen fertilization on the nutritional status, yield, and fruit quality of flame seedless grapevines grown in calcareous soils. Journal of Advanced Agriculture Research, 7 (1): 118-126.

Li P., Yang P. X ., Gou C.F., Han Y.D., Chang B.C. Rong E.C. and Wang Z.H. (1997). Response of pear trees cv. Suli to organic fertilization. Agric. Tech. Ext. Cent. Ningling country, Henan, China, Journal of Fruit Science, 14(4):262-264.

Mackinney G. (1941): Absorption of light by chlorophyll solutions. J. Biochem., 140:315-322.

Mahmoud H. M. and Mahmoud F. A. F. (1999). Studies on effect of some biofertilizers on growth of peach seedlings and root rot 
disease incidence. Egyptian Journal of Horticulture, 26(1):7-18.

Piper C.S. (1958). Soil and Plant Analysis. Inter. Sci. Pub., Inc. New York, 360-370.

Piper C.S. (1974). Soil and Plant Analysis.The University of Abdelaide, Australia.

Pregl F. (1945). Quantitative Organic Micro Analysis. $4^{\text {th }}$ Ed. J.A. Churchill Ltd., London, p.53.

Roan Sufeng, N. (1998): Effect of time of nitrogen application on growth of sand pear (Pyrus pyrifolia (Burm. F.) Nakai). Taichung District Agricultural Improvement Station 38: 215-222. (C.F. Hort.Abst. 68:6480).

Sendecor, G. W. and Cochran W. G. (1980). Statistical Methods. Oxford and J.B.H. Bub Com.state Univ. Press, Iowa U.S.A $6^{\text {th }}$ Edition.

Sharma S. D. and Bhutani V. P. (2000). Leaf nutrient status of apple seedlings as influenced by VAM, Azotobacter and inorganic fertilizers. Journal of Hill Research, 13 (2):63-66.

Steel R.G.D. and Torrie J.H. (1980). Reproduced from principles and procedures of statistics. Printed with the permission of C. I. Bliss, 448- 449.

Ystaas J. (1990). Pear tree nutrition. 4. Effects of different nitrogen supply via roots or leaves on yield, fruit size and fruit quality of "Moltke" pear. Acta- Agriculture Scandinavica, 40(4): 357-362.

Zhou X.W, Li Z.Y., Lu B., Chen X.N., X u L. J., Yi Y.W. X.W. and Yi Y. W. (2001). Study on the improvement of soil of the newly established orchard on the reclaimed purple soil. J. of Fruit Sci; 18(1):15-19 (c.f. CAB Abs. 1001-7364).

تأثثر النمو الخضرى والحالة الغذائية والمحصول في أشجار الكمثرى الليكونت ببعض معدلات الأسمدة العضوية والحيوية

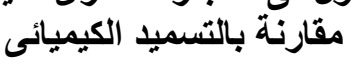

سميرة منصورمحمج ، طارق عبد العليم فايد ،عبد المنعم فتحى اسماعيل *ونور عبد السلام عبده*

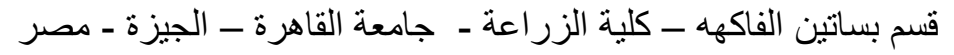

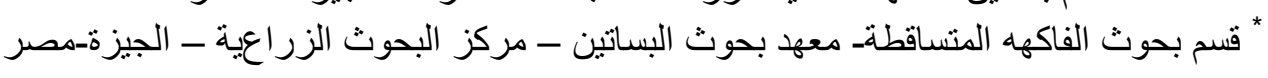

ملخص

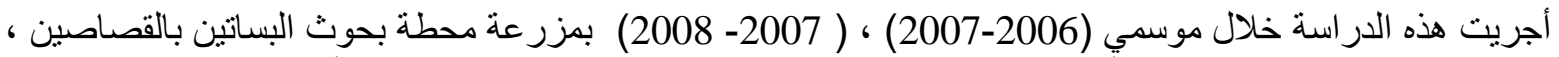

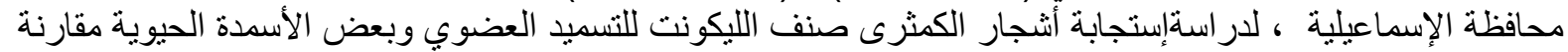

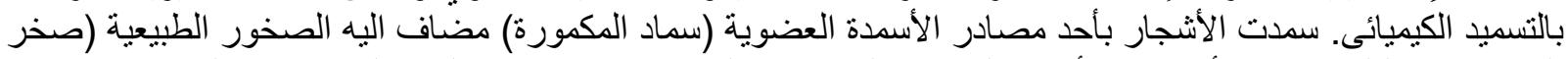

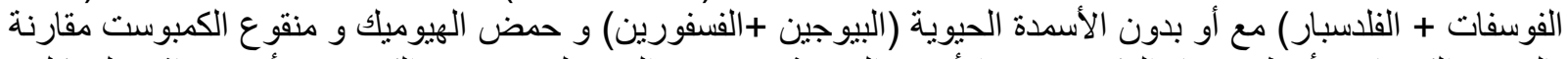

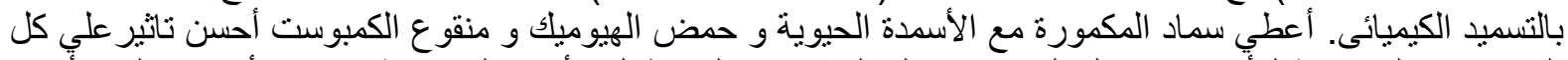

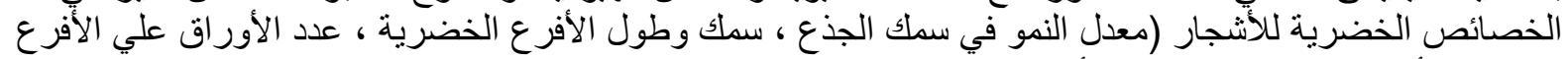

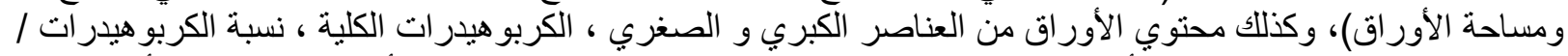

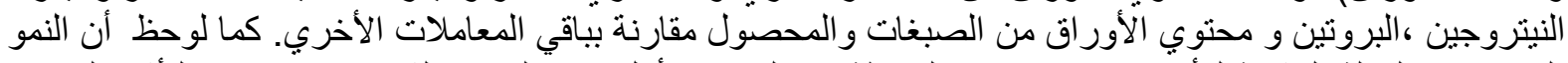

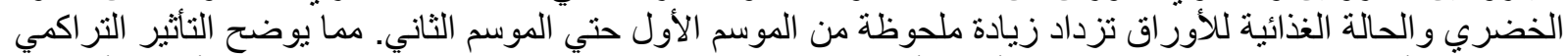

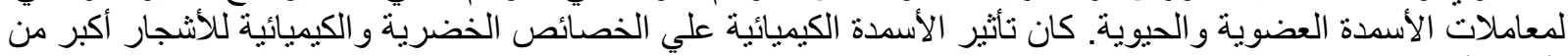
تأثير الأسمدة العضوية والحدة الحيوية علية عليها.

المجلة العلمية لكلية الزر اعة - جامعة القاهرة - المجلد (61) العدد الأول (يناير 2010 ) : 17-32. 